\title{
SWOT Analysis on RMB Settlement in Cross-border Trade in Fujian Province
}

\author{
Xiufeng Song \\ School of Economics and Management, Minjiang \\ University \\ Fuzhou, Fujian 350000
}

\author{
Haiyan Zhou \\ Fuzhou University of International Studies and Trade \\ Fuzhou \\ Fujian, 350202
}

\begin{abstract}
With the continuous advancement of the internationalization of the RMB, the RMB settlement business of cross-border trade in Fujian Province has become increasingly mature. Based on the analysis of the status quo of cross-Based on the analysis of the status quo of cross-border RMB settlement in Fujian Province, this paper comprehensively discusses the advantages, disadvantages, opportunities and challenges of crossborder RMB settlement in Fujian from multiple perspectives, and proposes countermeasures for the steady growth of settlement business to promote cross-border trade in RMB. order RMB settlement in Fujian Province, this paper comprehensively discusses the advantages, disadvantages, opportunities and challenges of cross-border RMB settlement in Fujian from multiple perspectives, and proposes countermeasures for the steady growth of settlement business to promote cross-border trade in RMB.
\end{abstract}

Keywords-Settlement in RMB; Cross-border trade; SWOT analysis

\section{INTRODUCTION}

In July 2009, the pilot work of RMB settlement of crossborder trade was launched fully. In June 2010, the People's Bank of China added 18 provinces (autonomous regions and municipalities directly under the Central Government), including Fujian Province, as pilot areas. After years of development, cross-border RMB settlement has played an important role in investment and trade facilitation in Fujian Province. Upon the implementation of the Belt and Road Initiative in October 2010, the RMB was formally included in the SDR a basket of currencies of the International Monetary Fund, and key progress has been made for RMB internationalization, which brings new development opportunities for cross-border RMB settlement in Fujian Province/. But at the same time, we also need to see that compared with the old international settlement currency, RMB cross-border settlement business is still at the early stage of development, RMB exchange rate depreciation, global political and economic turmoil and other factors still restrict the path of RMB cross-border settlement. Therefore, it has significant practical significance to explore the shortcomings and difficulties of RMB settlement for cross-border trade in Fujian Province at this stage, and conduct SWOT analysis, and put forward strategies to help the sustainable growth of RMB settlement business in Fujian Province.

\section{ANALYSIS ON THE CURRENT SITUATION OF RMB CROSS-BORDER SETTLEMENT BUSINESS IN FUJIAN PROVINCE}

In June 2010, Fujian Province confirmed to be a new pilot area of RMB settlement of cross-border trade. After more than eight years of development, the cross-border RMB settlement business in Fujian Province has developed vigorously, and the market entity's participation has significantly increased. According to the statistics of the People's Bank of China, by April 2011, Fujian Province had completed 1175 cross-border RMB business transactions, with an accumulated amount of RMB 25,508 billion, 20 commercial banks and 246 market entities. Of these, 111 cross-border settlements for export trade were handled, with an accumulated amount of RMB 581 million. As of August 2018, Fujian Province had over 16,000 market entities and 43 commercial banking institutions, including branches, had engaged in cross-border RMB settlement business.

After becoming a pilot area, Fujian Province has devoted itself to expanding the scope of cross-border RMB investment and financing settlement, simplifying the procedures for enterprises to handle relevant business with their own currencies and improving the timeliness, taking advantage of the "Belt and Road" policy, and constantly enhancing the influence of RMB in countries along the "Belt and Road". By the end of January 2018, 58 countries (regions) along the Belt and Road had cross-border RMB settlement transactions with Fujian Province, including RMB 65.357 billion for crossborder financing, RMB 42.481 billion for direct investment and RMB 77.778 billion for cross-border RMB settlement of goods trade.

With the implementation of the relevant policies of the People's Bank of China on improving cross-border RMB settlement in January 2018, Fujian Province responded positively and supported enterprises to use RMB for crossborder settlement; continuously implement the individual RMB cross-border settlement business and other policies in a more flexible manner. The dividends from cross-border RMB policy are beginning to benefit local businesses and people.

CLC No.: F822 Document reference number: A. 


\section{SWOT ANALYSIS ON PROMOTING CROSS-BORDER RMB SETTLEMENT IN FUJIAN PROVINCE}

Based on the current situation of cross-border RMB settlement business in Fujian Province, this paper uses SWOT analysis method to explore the strengths, weaknesses, opportunities and challenges in the development of RMB settlement business. As shown in Table 1.

TABLE I. SWOT ANALYSIS OF CROSS-BORDER RMB SETTLEMENT IN FUJIAN PROvinCE

\begin{tabular}{|c|c|c|c|}
\hline Strengths (S) & Weaknesses (W): & Opportunities (O) & Threats (T) \\
\hline $\begin{array}{c}\text { The trade scale grows } \\
\text { Steadily }\end{array}$ & $\begin{array}{c}\text { The Sino-Us trade } \\
\text { friction escalates. }\end{array}$ & $\begin{array}{c}\text { Diversified settlement } \\
\text { system becomes } \\
\text { consensus. }\end{array}$ & Demand for money is unstable. \\
\hline $\begin{array}{c}\text { Trade partner and } \\
\text { advantage of Fujian } \\
\text { businessmen }\end{array}$ & & $\begin{array}{c}\text { "Belt and Road" policy } \\
\text { support }\end{array}$ & $\begin{array}{c}\text { Impact on RMB Interest Rate and } \\
\text { Exchange Rate Control in China }\end{array}$ \\
\hline
\end{tabular}

\section{A. Advantage analysis}

1) The trade scale of Fujian province grows steadily

In recent years, the scale of foreign trade in Fujian Province has shown a relatively stable growth trend. As shown in Table 2, the total import and export value of Fujian Province in 2017 was RMB 1,159.08 billion, with a year-on-year growth of $12 \%$, of which RMB 711.41 billion was for export, with a growth of $4.1 \%$; Import value is RMB 447.67 billion, with a growth of $27.5 \%$. The sustained and steady growth of foreign trade has offered a relatively large demand space for RMB settlement.

TABLE II. IMPORT AND EXPORT VOLUME OF FUJIAN IN 2011-2017

\begin{tabular}{|c|c|c|c|c|}
\hline Items & $\begin{array}{c}\text { Total amount of } \\
\text { import and export }\end{array}$ & Year-on-year growth (\%) & Amount of imports & Amount of exports \\
\hline 2011 & 9269.8 & 25.9 & 5996.2 & 3273.6 \\
\hline 2012 & 9843.6 & 6.2 & 6175.7 & 3667.9 \\
\hline 2013 & 10486.4 & 6.5 & 6594.2 & 3892.3 \\
\hline 2014 & 10897.3 & 3.9 & 6968.9 & 3928.4 \\
\hline 2015 & 10478.4 & -3.8 & 6991.8 & 3486.6 \\
\hline 2016 & 10345.0 & -1.3 & 6833.7 & 3511.3 \\
\hline 2017 & 11590.8 & 12.0 & 7114.1 & 4476.7 \\
\hline
\end{tabular}

${ }^{\text {a. }}$ Unit: RMB 100 million

In addition, the willingness of cross-border trading entities to change the settlement currency is affected by the information search cost and related change costs. When the transaction scale of currency is larger, the transaction cost may be reduced due to the scale effect. The volume of foreign trade in Fujian Province is large, the transaction cost of changing settlement currency is low, and the main body of the transaction is relatively easy to accept the settlement currency change. b. Data source: Statistical Yearbook of Fujian Province

2) The structure of trade partners and the unique advantages of Fujian businessmen to develop RMB business

Currently, Fujian's trade partners are ranked as shown in Table 3 according to the scale of foreign trade. In 2017, the ASEAN region was the largest market for Fujian's foreign trade and it maintained a high growth rate of $17.7 \%$. The RMB has a bigger voice because of continuous growth in emerging trade markets.

TABLE III. STRUCtURE OF FUJIAN Foreign TRADE PARTNERS IN 2007

\begin{tabular}{|c|c|c|c|c|c|c|}
\hline Country or Region & ASEAN & USA & EU & Taiwan & Japan & Australia \\
\hline $\begin{array}{c}\text { Total amount of import } \\
\text { and export }\end{array}$ & 1925.5 & 1922.8 & 1613.1 & 774.6 & 665.4 & 486.9 \\
\hline $\begin{array}{c}\text { Year-on-year growth } \\
(\%)\end{array}$ & $17.70 \%$ & $14 \%$ & $8.70 \%$ & $18.30 \%$ & $9.70 \%$ & $37.50 \%$ \\
\hline
\end{tabular}

${ }^{c}$ Unit: RMB 100 million

According to statistics, about one fifth of the overseas Chinese are from Fujian, with a population of more than 10 million, distributed in more than 160 countries and regions in the world. To be more specific, more than 80 percent of
Taiwan compatriots are from Fujian, and more than 8 million Fujian-born overseas Chinese live in Southeast Asia, accounting for 80 percent of the world's Fujian-born overseas Chinese. Therefore, Fujian businessmen have strong economic 
strength and far-reaching influence in ASEAN and Taiwan. ASEAN and Taiwan are the main trade partners of Fujian, and their kinship, geographic, cultural and commercial ties have become an important catalyst for Fujian to promote RMB settlement.

\section{B. Disadvantage analysis}

Sino-US trade friction escalates and conflict deepens, US is the second largest foreign trade market of Fujian Province but since 2018, the increasingly fierce Sino-US trade war has weakened the export advantage of Fujian Province, affected Sino-US trade, and slowed down the pace of RMB settlement of foreign trade in Fujian. The US regards China as a strategic competitor, trying to hinder the development of China's hightech industry, and seeking to confine China's manufacturing industry to the low-end of the global value chain. As a global power, the attitude of the US towards China also affects other trade partners, and the negative demonstration effect will hinder the process of RMB settlement of foreign trade in Fujian Province.

\section{Opportunity analysis}

1) Diversified settlement system becomes consensus

In order to jointly resist the international financial crisis, the establishment of a multiple settlement system is the basic consensus of all countries, and the implementation of crossborder trade RMB settlement provides a new scheme for the world. The sub-prime mortgage crisis in the United States has made people deeply aware of the defects of the international monetary system with "US dollar dominant " and the necessity of reforming the existing monetary system, which provides the basic conditions for China to carry out the pilot RMB settlement system, and RMB settlement gradually occupies a place in the international monetary system.

\section{2) "Belt and Road" Initiative}

The internationalization of RMB and the Belt and Road Initiative are the two key points for China to build an open economy, both of which have close internal links and broad space for synergetic development. Fujian Province is treated as the "21st Century Maritime Silk Road Core Area" explicitly supported by the central government, and the "Belt and Road" initiative provides new opportunities for cross-border RMB business in Fujian Province. With the help of the Belt and Road Initiative, the provincial financial institutions have taken the initiative to support enterprises to actively use RMB for trade, investment and financing settlement, and constantly enhance the influence of RMB in neighboring countries.

\section{Threat Analysis}

1) Monetary demand is unstable, which affects the effectiveness of monetary policy

When cross-border RMB settlement becomes a common phenomenon, the circulation of RMB breaks through the national boundary. The demand for RMB is not only affected by internal factors such as the total price and circulation speed of domestically produced circulated commodities, but also affected by the foreign economic situation to some extent, and the demand for RMB becomes more and more unpredictable.
As we all know, the monetary policy adjustment tool is money supply, under the background of the uncertain change of money demand, the money supply will be more difficult to determine, which will inevitably affect the effectiveness of monetary policy. In addition, when RMB becomes the crossborder settlement currency, the foreign market trading subjects will hold RMB, which will form the foreign debt of the Central Bank of China, and also bring certain challenges for the Central Bank to formulate macro-monetary policy.

2) Overseas $R M B$ interest rate and exchange rate shocks domestic $R M B$ interest rate and exchange rate control

As the scope of cross-border RMB settlement business gradually increases and the scale of RMB circulation expands, the degree of marketization of RMB exchange rate and interest rate outside China is becoming increasingly prominent, and finally achieves complete marketization. Domestic RMB exchange rate and interest rates will inevitably be affected and impacted by the fluctuations of the RMB market outside China, increasing more unstable factors. As mentioned above, with the continuous expansion of cross-border RMB circulation scale, the problem of cross-border RMB currency arbitrage and interest arbitrage may occur on a wide range, which brings more difficulties and challenges for the Central Bank to formulate monetary policy and determine the domestic interest rate and exchange rate.

\section{STRATEGIES FOR PROMOTING RMB SETTLEMENT IN CROSS-BORDER TRADE}

\section{A. Foreign trade enterprises should increase the frequency of commodities trading with neighboring countries and gradually adopt RMB for settlement.}

At this stage, the international market for commodities trading has been settled by the United States dollar, the strong position of the United States dollar is difficult to change in a short period of time. Domestic market entities use RMB as the settlement currency, which can avoid the exchange rate risk and exchange cost caused by US dollar to a certain extent. China is the "world factory" of manufacturing industry, the manufacturing and processing base of supplied materials, and there is a great demand and gap for energy, raw materials and parts. Most of our neighboring countries have abundant natural endowments, and our foreign trade enterprises can increase the frequency of commodity trade with the neighboring countries, and gradually improve the scale and scope of cross-border RMB settlement.

In recent years, the pace of economic integration between China and ASEAN has been increasing, the scale of trade between the two sides has expanded significantly, and China has a sustained trade surplus with ASEAN. Domestic foreign trade enterprises can, based on this advantage, advocate using RMB as the currency for transaction settlement, simplify the exchange procedures and expand the demand for RMB settlement of commodities in the ASEAN region. 


\section{B. Improve the Service Level of RMB Settlement Business of China's Commercial Banks}

The prospect of cross-border RMB settlement business development is also largely affected by the service quality of commercial banks and other financial institutions, and commercial banks should focus on promoting various businesses involving RMB settlement.

In addition, commercial banks should actively open up and expand channels for domestic enterprises to invest abroad, provide services for RMB "going out" business, increase the scale of RMB circulation abroad, and realize the promotion of RMB settlement business to capital project. At the same time, the expansion of RMB settlement scale will also cause certain risks, and commercial banks should also accordingly launch RMB settlement hedging products.

\section{Government departments should improve relevant policies to facilitate RMB settlement.}

Relevant government departments should improve various policies and regulations, simplify RMB settlement procedures, reduce RMB settlement costs, extend the restrictions on RMB settlement, so as to provide convenience for RMB settlement, create trade opportunities for RMB settlement, and further expand the demand for RMB settlement.

Based on the analysis of the current situation of crossborder RMB settlement in Fujian Province, this paper discusses the strengths and weaknesses, opportunities and challenges of cross-border RMB settlement in Fujian Province, and puts forward some countermeasures and suggestions to improve the service level of RMB settlement business of China's commercial banks and improve relevant policies.

\section{ACKNOWLEDGMENT}

About the Author: Xiufeng SONG (1968-), male, Han nationality, born in Mudanjiang, Heilongjiang Province, Associate Professor of School of Economics and Management, Minjiang University, Ph.D., research direction: International Trade Haiyan ZHOU (1992-), female, Han nationality, born in Fuzhou of Fujian Province, TA of Fuzhou University of International Studies and Trade, master degree,research direction: Public Economics, International Economics and Trade.

Funding Project: This paper is the research achievement of the social science research project B of Fujian Provincial Education Department, "Analysis on the Advantages and Existing Problems of RMB Settlement in Expanding Crossborder Trade in Fujian Province" (Project No.: JB13326S).

\section{REFERENCES}

[1] Jing LI On RMB Internationalization Strategy from the Perspective of RMB Settlement of Cross-border Trade [J]. Word Economy Studies, 2011, (02): 13-19+87

[2] Cong YANG Risk and Precaution of RMB Settlement in Cross-border Trade [J]. Management World, ,2011(10): 170-171.

[3] Wenting TAO. Research on RMB Settlement of Cross-border Trade [D]. East China Normal University 2013.

[4] Jing ZHANG. Research on the Advantages of Fujian Province in Expanding RMB Settlement of Cross-border Trade [J]. Journal of Yibin University, 2012, 12 (10): 56-60.

[5] Ning YU. SWOT Analysis and Countermeasures of RMB Settlement of Cross-border Trade [J]. Modern Economic Information, 2017(07): 304.

[6] Mingxian FANG. Research on Specific Factors Affecting Cross-border RMB Settlement [J]. Shanghai Finance. 2015 (01): 108-110.

[7] Weidong HUO, Fuhua DENG. Financial Development and RMB Settlement of Cross-border Trade--An Empirical Study Based on Provincial Panel Data [J]. Journal of International Trade, 2015(08): 145 155. 